\title{
Population analysis of xenobiotic metabolizing genes in South Brazilian Euro and Afro-descendants
}

\author{
Marcos Euzébio Maciel, Fausto Koga Oliveira, Gustavo Bonfim Propst, Maria da Graça Bicalho,
} Iglenir João Cavalli and Enilze Maria de Souza Fonseca Ribeiro

Departamento de Genética, Universidade Federal do Paraná, Curitiba, PR, Brazil.

\begin{abstract}
Individual variability in xenobiotic metabolism has been associated with susceptibility to developing complex diseases. Genes involved in xenobiotic metabolism have been evaluated in association studies; the difficulty of obtaining accurate gene frequencies in mixed populations makes interpretation of the results difficult. We sought to estimate population parameters for the cytochrome P450 and glutathione S-transferase gene families, thus contributing to studies using these genes as markers. We describe the frequencies of six genes (CYP1A1, CYP2D6, CYP2E1, GSTM1, GSTT1, and GSTP1) and estimate population parameters in 115 Euro-descendants and 196 Afro-descendants from Curitiba, South of Brazil. PCR-based methods were used for genotyping, and statistical analysis were performed by AMOVA with ARLEQUIN software. The mutant allele frequencies in the Afro-descendants and Euro-descendants, respectively, were: $C Y P 1 A 1^{\star} 2 A=30.1 \%$ and $15.2 \% ; C Y P 2 D 6^{*} 4=14.5 \%$ and $21.5 \%$; CYP2E $1{ }^{*} 5 B=7.9 \%$ and $5 \%$; GSTP $1{ }^{*} B=37.8 \%$ and $28.3 \%$. The null genotype frequencies were: $G S T M 1{ }^{*} 0=36.8 \%$ and $46.1 \%$; $G S T T 1{ }^{*} O=24.2 \%$ and $17.4 \%$.
\end{abstract}

Key words: CYP, GST, population study.

Received: April 29, 2009; Accepted: July 27, 2009.

Genetic marker studies assessing individual backgrounds from specific populations can provide information on gene flow, evolutionary history, and population dispersions, and can also help in the prediction of risks for particular diseases. Based on these studies, pharmacogenetic data have shown significant inter- and intra-population differences in the metabolism, efficiencies, and toxicities of several types of drugs. These findings have important implications for the management and treatment of human diseases (Kittles and Weiss, 2003).

Many different enzyme families are involved in xenobiotic metabolism, including cytochrome P450 (CYPs) in phase I, as well as glutathione S-transferases (GSTs) and $\mathrm{N}$-acetyl-transferases (NATs) in phase II (Autrup, 2000). Several genes of the CYP family have been studied in many populations (e.g., Europeans, Africans, Asians, and their mixed descendants) in case-control studies of complex diseases. With regard to cancers, these studies focus primarily on lung, breast, and head and neck tumors (Olshan et al., 2000; Gajecka et al., 2005; Yang et al., 2005; Leichsenring et al., 2006; Losi-Guembarovski et al., 2008; Torresan et al., 2008; Varela-Lema et al., 2008).

Send correspondence to Enilze M.S.F. Ribeiro. Departamento de Genética, Universidade Federal do Paraná, Caixa Postal 19071, 81531-970 Curitiba, PR, Brazil. E-mail: eribeiro@ufpr.br.
Variants of GSTs enzymes have been extensively studied and were found to be associated with several types of neoplasias in different populations, such as Europeans and Euro-descendants (Park et al., 2000; Geisler and Olshan, 2001; Raimondi et al., 2005; Leichsenring et al., 2006; Losi-Guembarovski et al., 2008; Torresan et al., 2008), Africans and Afro-descendants (Dandara et al., 2002; Enokida et al., 2005), and Asians (Yang et al., 2005). Other studies involving genes of xenobiotic metabolism have been performed in order to describe the frequency of the mutant alleles and genotypes in different healthy populations (Garte et al., 2001; Gaspar et al., 2002; Menoyo et al., 2006). Some studies carried out in the Brazilian population described mutant allele and genotype frequencies in several regions (Arruda et al., 1998; Gattás and Soares Viera, 2000; Gaspar et al., 2002; Losi-Guembarovski et al., 2002; Rossini et al., 2002; Amorim et al., 2004; Gattás et al., 2004; Hatagima et al., 2004; Kvitko et al., 2006; Rossini et al., 2006).

In the present report, two distinct groups (Euro-descendants and Afro-descendants) from Curitiba in the South of Brazil were analyzed in order to describe the frequency of six metabolic genes (CYP1A1, CYP2E1, CYP2D6, GSTM1, GSTT1, and GSTP1). The group of Euro-descendants was comprised of 115 healthy individuals ( 49 males 
and 66 females) with an average age of $42.6 \pm 7.3$ years. The group of Afro-descendants was comprised of 196 healthy individuals (123 males and 73 females) with an average age of $33.4 \pm 8.6$ years. The ethnic differentiation from these groups was determined through a survey with self-declared information from the individuals that was attached to the Informed Consent agreement. The blood samples were collected in the Hematology and Hemotherapy Center of Paraná State (HEMEPAR), a center for blood donation, by the staff of the Immunogenetics and Histocompatibility Laboratory (LIGH). Genomic DNA was isolated from peripheral white blood cells from all individuals and sampled by a salting out procedure (Bignon and Fernandez-Viña, 1997). Polymerase chain reaction (PCR) primers were designed according to the Genome Data Bank. The genotyping of $C Y P 1 A 1 * 2 A, C Y P 2 D 6 * 4, C Y P 2 E 1 * 5 B$, and $G S T P 1{ }^{*} B$ was performed by PCR RFLP according to the following protocols, respectively: Carstensen et al. (1993), Sobtia et al. (2005), Kato et al. (1992), and Harries et al. (1997). GSTM1*0 and GSTT1*0 genotyping was performed by PCR multiplex according to the protocol described by Abdel-Rahman et al. (1996).

The allele frequencies of the $C Y P 1 A 1 * 2 A$, $C Y P 2 D 6 * 4, C Y P 2 E^{*} 5 B, G S T P 1 * B$ and the null genotypes $G S T M 1 * 0$ and $G S T T 1 * 0$ were obtained by direct counting. The Chi-square test was used to: 1) compare the frequencies of dominant and recessive genotypes of the genes $G S T M 1 * 0$ and $G S T T 1 * 0$ in individuals of the Euro and Afro-descendant groups, 2) verify whether the genes $C Y P 1 A 1 * 2 A, C Y P 2 D 6 * 4, C Y P 2 E^{*} 5 B$, and GSTP1*B were in Hardy-Weinberg equilibrium (HWE), and 3) compare the frequencies of the mutant allele of these genes and the genotypes GSTM $1 * 0$ and GSTT1*0 with published data. The frequencies of $C Y P 1 A 1 * 2 A, C Y P 2 D 6 * 4, C Y P 2 E * 5 B$, and $G S T P 1^{*} B$, genotyped in 311 unrelated persons $(622$ chromosomes) in both samples, were compared via the analysis of the molecular variance (ARLEQUIN 3.1) according to Excoffier et al. (1992). The fixation index (Fst) was estimated for the entire sample.

The two groups studied were in Hardy-Weinberg equilibrium with regard to genotype frequencies of the genes $C Y P 1 A 1 * 2 A, \quad C Y P 2 D 6^{*} 4, \quad C Y P 2 E^{*} 5 B$ and $G S T P 1 * B$. The mutant allele and null genotype frequencies found in the present study were compared with others described in the literature from both non-Brazilian and Brazilian populations (data presented in Tables 1 and 2). When our data were compared with literature data from nonBrazilian Afro-descendants, the frequencies of individuals with mutant alleles for the genes CYP2D6*4, GSTP $1 * B$ and null genotype $G S T M 1{ }^{*} 0$ were not homogeneously distributed between the populations of this study (Table 1).
We believe that this discrepancy is due to the different methods used for the classification of ethnic origin among research groups, in spite of the parental population from North and South America may have different gene frequencies. In this sense is important to notice that the partial $\chi^{2}$ values from our sample were the main responsible for the observed significance. On the other hand, the frequencies of individuals with mutant alleles and null genotypes $(\mathrm{GSTM} 1 * 0$ and GSTT $1 * 0)$ for the genes studied were homogeneously distributed between populations when the non-Brazilian Europeans and Euro-descendants were considered (Table 1). The frequencies of individuals with mutant alleles and null genotypes in Brazil, both for Afro-and Euro-descendants were homogeneously distributed (Table 2).

In the comparison of our groups we noticed that there was a homogeneous distribution of the frequency of the genotypes $G S T M 1 * 0$ and $G S T T 1 * 0$ between the Afro-descendants and Euro-descendants; the differences of the frequencies of individuals with dominant and recessive genotypes, respectively, were statistically not significant $\left(\chi_{1}^{2}=2.52\right.$; $\mathrm{p} \pm 0.10$ and $\left.\chi^{2}{ }_{1}=1.97 ; \mathrm{p}>0.10\right)$. The analysis of molecular variance (AMOVA) for the genes CYP1A1*2A, $C Y P 2 D 6^{*} 4, C Y P 2 E 1 * 5 B$, and $G S T P 1 * B$ showed that $97.47 \%$ of the component of genetic variance is present within the ethnic groups and $2.53 \%\left(\mathrm{p}<10^{-4}\right)$ between them. This lower value justify the lower value of the fixation index or co-ancestry coefficient $(\mathrm{Fst}=0.02508$ and 0.02565 for Afro- and Euro-descendants, respectively, and 0.02529 for the entire group) observed in this study. $F_{\text {st, }}$ is computed as a measure of the population division effect and values up to 0.05 indicate negligible genetic differentiation (Adeyemo et al., 2005).

Biometabolism genes have been widely used in association studies, and they have contributed to the improvement in understanding the genetic basis of quantitative features (e.g., susceptibility to complex diseases and drug response). Such studies must consider the impact of the population stratification and miscegenation degree of the control population (Ardlie et al., 2002; Freedman et al., 2004) in order to prevent false associations (Zembrzuski et al., 2006). When genes with ethnic variation frequencies are evaluated in association studies (especially in complex diseases with multiple environmental and genetic factors), the high-risk group may present a low prevalence of the high-risk allele if other genetic or environmental risk factors predominate in that group (Ziv and Burchard, 2003).

The present report provides data that can contribute to the general profile of frequency and population dynamics of biometabolizing genes in groups of the Southern Brazilian population. These data constitute a valuable resource for the planning of future association studies in complex diseases like cancers. 


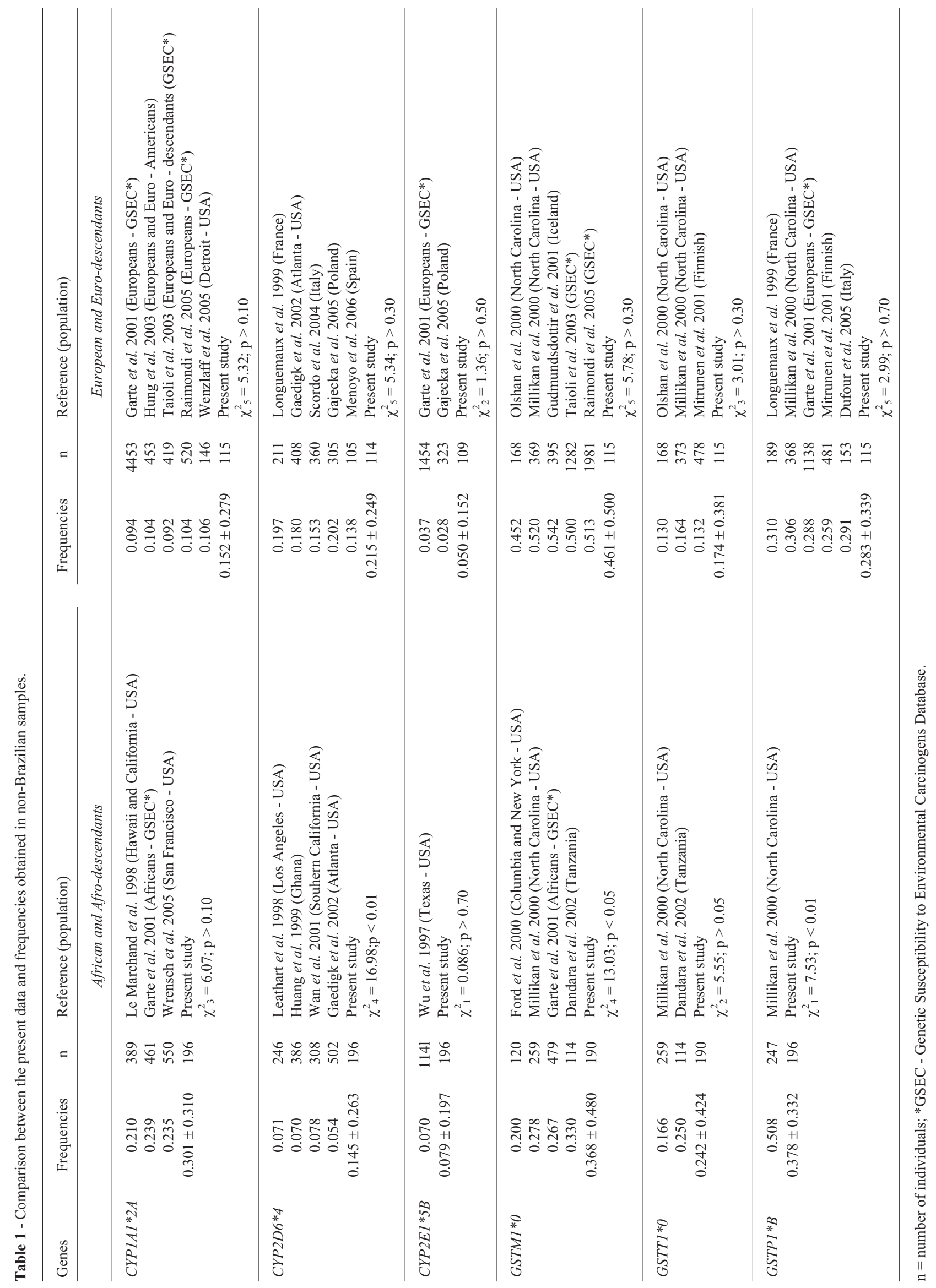


Table 2 - Comparison between the present data and frequencies obtained in other Brazilian samples

\begin{tabular}{|c|c|c|c|c|c|c|}
\hline \multirow[t]{2}{*}{ Genes } & Frequencies & $\mathrm{n}$ & Authors (Brazilian region) & Frequencies & $\mathrm{n}$ & Authors (Brazilian region) \\
\hline & \multicolumn{3}{|r|}{ Afro-descendants } & \multicolumn{3}{|c|}{ Euro-descendants } \\
\hline$C Y P 1 A 1 * 2 A$ & $\begin{array}{c}0.305 \\
0.301 \pm 0.310\end{array}$ & $\begin{array}{l}100 \\
196\end{array}$ & $\begin{array}{l}\text { Kvitko et al. } 2006 \text { (South) } \\
\text { Present study } \\
\chi_{1}^{2}=0.005 ; \mathrm{p}>0.90\end{array}$ & $\begin{array}{c}0.106 \\
0.173 \\
0.152 \pm 0.279\end{array}$ & $\begin{array}{r}85 \\
90 \\
115\end{array}$ & $\begin{array}{l}\text { Torresan et al., } 2008 \text { (South) } \\
\text { Kvitko et al. } 2006 \text { (South) } \\
\text { Present study } \\
\chi_{2}^{2}=1.64 ; \mathrm{p}>0.30\end{array}$ \\
\hline$C Y P 2 E 1 * 5 B$ & $\begin{array}{c}0.029 \\
0.058 \\
0.079 \pm 0.197\end{array}$ & $\begin{array}{r}136 \\
86 \\
196\end{array}$ & $\begin{array}{l}\text { Gattás et al. } 2000 \text { (Southeast) } \\
\text { Rossini et al. } 2006 \text { (Southeast) } \\
\text { Present study } \\
\chi^{2}{ }_{2}=3.71 ; \mathrm{p}>0.10\end{array}$ & $\begin{array}{c}0.069 \\
0.061 \\
0.050 \pm 0.1521\end{array}$ & $\begin{array}{r}151 \\
66 \\
109\end{array}$ & $\begin{array}{l}\text { Rossini et al. } 2006 \text { (Southeast) } \\
\text { Torresan et al., } 2008 \text { (South) } \\
\text { Present study } \\
\chi_{2}^{2}=0.40 ; \mathrm{p}>0.80\end{array}$ \\
\hline CYP2D6*4* & - & - & - & $\begin{array}{c}0.188 \\
0.215 \pm 0.249\end{array}$ & $\begin{array}{r}85 \\
114\end{array}$ & $\begin{array}{l}\text { Torresan et al., } 2008 \text { (South) } \\
\text { Present study } \\
\chi_{1}^{2}=0.21 ; \mathrm{p}>0.50\end{array}$ \\
\hline GSTM1*0 & $\begin{array}{c}0.330 \\
0.342 \\
0.328 \\
0.340 \\
0.368 \pm 0.480\end{array}$ & $\begin{array}{l}117 \\
272 \\
137 \\
100 \\
190\end{array}$ & $\begin{array}{l}\text { Arruda et al. } 1998 \text { (Northeast) } \\
\text { Rossini et al. } 2002 \text { (Southeast) } \\
\text { Gattás } \text { et al. } 2004 \text { (Southeast) } \\
\text { Kvitko et al. } 2006 \text { (South) } \\
\text { Present study } \\
\chi^{2}{ }_{4}=0.72 ; \mathrm{p}>0.90\end{array}$ & $\begin{array}{c}0.450 \\
0.489 \\
0.446 \\
0.500 \\
0.463 \\
0.461 \pm 0.500\end{array}$ & $\begin{array}{r}130 \\
319 \\
233 \\
90 \\
95 \\
115\end{array}$ & $\begin{array}{l}\text { Arruda et al. } 1998 \text { (Southeast) } \\
\text { Rossini et al. } 2002 \text { (Southeast) } \\
\text { Gattás et al. } 2004 \text { (Southeast) } \\
\text { Kvitko et al. } 2006 \text { (South) } \\
\text { Torresan et al., } 2008 \text { (South) } \\
\text { Present study } \\
\chi^{2}{ }_{5}=1.65 ; \mathrm{p}>0,80\end{array}$ \\
\hline$G S T T 1 * 0$ & $\begin{array}{c}0.190 \\
0.257 \\
0.263 \\
0.280 \\
0.242 \pm 0.424\end{array}$ & $\begin{array}{l}117 \\
272 \\
137 \\
100 \\
190\end{array}$ & $\begin{array}{l}\text { Arruda et al. } 1998 \text { (Northeast) } \\
\text { Rossini et al. } 2002 \text { (Southeast) } \\
\text { Gattás et al. } 2004 \text { (Southeast) } \\
\text { Kvitko et al. } 2006 \text { (South) } \\
\text { Present study } \\
\chi^{2}{ }_{4}=3.14 ; \mathrm{p}>0.50\end{array}$ & $\begin{array}{c}0.185 \\
0.215 \\
0.223 \\
0.211 \\
0.295 \\
0.174 \pm 0.381\end{array}$ & $\begin{array}{r}130 \\
319 \\
233 \\
90 \\
95 \\
115\end{array}$ & $\begin{array}{l}\text { Arruda et al. } 1998 \text { (Southeast) } \\
\text { Rossini et al. } 2002 \text { (Southeast) } \\
\text { Gattás et al. } 2004 \text { (Southeast) } \\
\text { Kvitko et al. } 2006 \text { (South) } \\
\text { Torresan } \text { et al., } 2008 \text { (South) } \\
\text { Present study } \\
\chi_{5}^{2}=5.53 ; \mathrm{p}>0,20\end{array}$ \\
\hline$G S T P 1 * B$ & $\begin{array}{c}0.420 \\
0.378 \pm 0.332\end{array}$ & $\begin{array}{l}100 \\
196\end{array}$ & $\begin{array}{l}\text { Kvitko et al. } 2006 \text { (South) } \\
\text { Present study } \\
\chi_{1}^{2}=0.50 ; p>0.30\end{array}$ & $\begin{array}{c}0.315 \\
0.278 \\
0.330 \\
0.283 \pm 0.339\end{array}$ & $\begin{array}{r}319 \\
90 \\
85 \\
115\end{array}$ & $\begin{array}{l}\text { Rossini et al. } 2002 \text { (Southeast) } \\
\text { Kvitko et al. } 2006 \text { (South) } \\
\text { Torresan } \text { et al., } 2008 \text { (South) } \\
\text { Present study } \\
\chi^{2}{ }_{3}=0.99 ; \mathrm{p}>0.80\end{array}$ \\
\hline
\end{tabular}

$\mathrm{n}=$ number of individuals; * no data to compare.

\section{Acknowledgments}

Research support from CAPES, CNPq and Fundação Araucária are gratefully acknowledged. We sincerely thank Dr Luciane Regina Cavalli for suggestions.

\section{References}

Abdel-Rahman SZ, El-Zein RA, Anwar WA and Au WW (1996) A multiplex PCR procedure for polymorphic analysis of GSTM1 and GSTT1 genes in population studies. Cancer Lett 107:229-233.

Adeyemo AA, Chen G, Chen Y and Rotimi C (2005) Genetic structure in four West African population groups. BMC Genet 6:38.

Amorim LM, Lotsch PF, Simão TDT de A, Gallo CV and Pinto LF (2004) Analysis of CYP1A1 exon 7 polymorphisms by PCR-SSCP in a Brazilian population and description of two novel gene variations. Mutat Res 547:35-40.

Ardlie KG, Lunetta KL and Seielstad M (2002) Testing for population subdivision and association in four case-control studies. Am J Hum Genet 71:304-311.

Arruda VR, Grignolli CE, Gonçalves MS, Soares MC, Menezes R, Saad STO and Costa FF (1998) Prevalence of homo- zygosity for the deleted alleles of glutatione S-transferase mu (GSTM1) and theta (GSTT1) among distinct ethnic groups from Brazil: Relevance to enviromental carcinogenesis? Clin Genet 54:210-214.

Autrup H (2000) Genetic polymorphisms in human xenobiotic metabolizing enzymes as suscetibility factors in toxic response. Mutat Res 464:65-76.

Bignon JD and Fernandez-Viña MA (1997) Protocols of the 12th Internacional Histocompatibility Workshop for typing of HLA class II alleles by DNA amplification by the polymerase chain reaction (PCR) and hybridization with sequence specific oligonucleotide probes (SSOP). In: Charron D (ed) HLA. Genetic Diversity of HLA: Functional and Medical Implications. Proceedings of the 12th International Histocompatibility Workshop and Conference, v. 1. EDK, Paris, pp 584-595.

Carstensen U, Alexandrie AK, Högstedt B, Rannug A, Bratt I and Hagmar L (1993) Band T- lymphocyte micronuclei in chimney sweeps with respect to genetic polymorphism for CYP1A1 and GSTM1 (Class Mu). Mutat Res 289:187-195.

Dandara C, Sayi J, Masimirembwa CM, Magimba A, Kaaya S, De Sommers K, Snyman JR and Hasler JA (2002) Genetic polymorphism of cytochrome P450 1A1 (CYP1A1) and glu- 
tathione transferases (M1, T1 and P1) among Africans. Clin Chem Lab Med 40:952-957.

Dufour C, Svahn J, Bacigalupo A, Longoni D, Varotto S, Iori AP, Bagnasco F, Locasciulli A, Menna G, U Ramenghi, et al. (2005) Genetic polymorphisms of CYP3A4, GSTT1, GSTM1, GSTP1 and NQO1 and the risk of acquired idiopathic aplastic anemia in Caucasian patients. Haematologica 90:1027-1031.

Enokida H, Shiina H, Urakami S, Igawa M, Ogishima T, Pookot D, Li LC, Tabatabai ZL, Kawahara M, Nakagawa M, et al. (2005) Ethnic grouprelated differences in CpG hypermethylation of the GSTP1 gene promoter among AfricanAmerican, Caucasian and Asian patients with prostate cancer. Int J Cancer 116:174-181.

Excoffier L, Smouse PE and Quattro JM (1992) Analysis of molecular variance inferred from metric distances among DNA haplotypes: Application to human mitochondrial DNA restriction data. Genetics 131:592-608.

Ford JG, Li Y, O'Sullivan MM, Demopoulos R, Garte S, Taioli E and Brandt-Rauf PW (2000) Glutathione S-transferase M1 polymorphism and lung cancer risk in African-Americans. Carcinogenesis 21:1971-1975.

Freedman ML, Reich D, Penney KL, Mcdonald GJ, Mignault AA, Patterson N, Gabriel SB, Topol EJ, Smoller JW, Pato CN, et al. (2004) Assessing the impact of population stratification on genetic association studies. Nat Genet 36:388-393.

Gaedigk A, Bradford LD, Marcucci KA and Leeder JS (2002) Unique CYP2D6 activity distribution and genotype-phenotype discordance in black Americans. Clin Pharmacol Ther 72:76-89.

Gajecka M, Rydzanicz M, Jaskula-Sztul R, Kujawski M, Szyfter W and Szyfter Z (2005) CYP1A1, CYP2D6, CYP2E1, NAT2, GSTM1 and GSTT1 polymorphisms or their combinations are associated with the increased risk of the laryngeal squamous cell carcinoma. Mutat Res 574:112-123.

Garte S, Gaspari L, Alexandrie AK, Ambrosone C, Autrup H, Autrup JL, Baranova H, Bathum L, Benhamou S, Boffetta P, et al. (2001) Metabolic gene polymorphisms frequencies in control populations. Cancer Epidemiol Biomarkers Prev 10:1239-1248.

Gaspar PA, Kvitko K, Papadopolis LG, Hutz MH and Weimer TA (2002) High frequency of CYP1A1*2C allele in Brazilian populations. Hum Biol 74:235-242.

Gattás GJF and Soares-Vieira JA (2000) Cytochrome P450-2E1 and glutathione S-transferase mu polymorphisms among Caucasians and Mulattoes from Brazil. Occup Med 50:508511.

Gattás GJF, Kato M, Soares-Vieira JA, Siraque MS, Kohler P, Gomes L, Rego MAV and Bydlowski SP (2004) Ethnicity and glutathione S-transferase (GSTM1/GSTT1) polymorphisms in a Brazilian population. Braz J Med Biol Res 34:451-458.

Geisler SA and Olshan AF (2001) GSTM1, GSTT1, and the risk of squamous cell carcinoma of the head and neck: A minihuge review. Am J Epidemiol 154:95-103.

Gudmundsdottir K, Tryggvadottir L and Eyfjord JE (2001) GSTM1, GSTT1, and GSTP1 genotypes in relation to breast cancer risk and frequency of mutations in the p53 gene. Can Epidemiol Biom Prev 10:1169-1173.

Harries LW, Stubbins MJ, Forman D, Howard GC and Wolf CR (1997) Identification of genetic polymorphisms at the gluta- thione S-transferase Pi locus and association with suscetibility to bladder, testicular and prostate cancer. Carcinogenesis 18:641-644.

Hatagima A, Marques CF, Krieger H and Feitosa MF (2004) Glutatione S-transferase M1 (GSTM1) and T1 (GSTT1) polymorphisms in a Brazilian mixed population. Hum Biol 76:937-942.

Huang CS, Shen CY, Chang KJ, Hsu SM and Chern HD (1999) Cytochrome P4501A1 polymorphism as a susceptibility factor for breast cancer in postmenopausal Chinese women in Taiwan. Br J Cancer 80:1838-1843.

Hung RJ, Boffetta P, Brockmöller J, Butkiewicz D, Cascorbi I, Clapper ML, Garte S, Haugen A, Hirvonen A, Anttila S, et al. (2003) CYP1A1 and GSTM1 genetic polymorphisms and lung cancer risk in Caucasian non-smokers: A pooled analysis, Carcinogenesis 24:875-882.

Kato S, Shields PG, Caporaso NE, Sugimura H, Trivers GE, Tucker MA, Trump BF, Weston A and Harris CC (1992) Cytochrome P450IIEI genetic polymorphisms racial variation and lung cancer risk. Cancer Res 56:6712-6715.

Kittles RA and Weiss KM (2003) Race, ancestry, and genes: Implications for defining disease risk. Annu Rev Genomics Hum Genet 4:33-67.

Kvitko K, Gaspar PA, Torres AR and Hutz M (2006) CYP1A1, GSTM1, GSTT1 and GSTP1 polymorphisms in an Afrobrazilian group. Genet Mol Biol 29:613-616.

Le Marchand L, Sivaraman L, Pierce L, Seifried A, Lum A, Wilkens LR and Lau AF (1998) Associations of CYP1A1, GSTM1, and CYP2E1 polymorphisms with lung cancer suggest cell type specificities to tobacco carcinogens. Cancer Res 58:4858-4863.

Leathart JB, London SJ, Steward A, Adams JD, Idle JR and Daly AK (1998) CYP2D6 phenotype-genotype relationships in African-Americans and Caucasians in Los Angeles. Pharmacogenetics 8:529-541.

Leichsenring A, Losi-Guembarovski R, Maciel ME, Losi-Guembarovski A, Oliveira BW, Ramos G, Cavalcanti TCS, Bicalho MG, Cavalli IJ, Cólus IMS, et al. (2006) CYP1A1 and GSTP1 polymorphisms in an oral cancer case-control study. Braz J Med Biol Res 39:1569-1574.

Longuemaux S, Deloménie C, Gallou C, Méjean A, Vincent-Viry M, Bouvier R, Droz D, Krishnamoorthy R, Galteau M, Junien C, et al. (1999) Candidate genetic modifiers of individual susceptibility to renal cell carcinoma:a study of polymorphic human xenobiotic-metabolizing enzymes. Cancer Res 59:2903-2908.

Losi-Guembarovski R, D'arce LPG and Cóllus IMS (2002) Glutathione S-transferase mu (GSTM1) null genotype in relation to gender, age and smoking status in a healthy Brazilian population. Genet Mol Biol 25:357-360.

Losi-Guembarovski R, Cóllus IMS, De Menezes RP, Poliseli F, Chaves VN, Kuasne H, Leichsenring A, Guembarovski AL, Oliveira BW, Ramos G, et al. (2008) Lack of association among polymorphic xenobiotic-metabolizing enzyme genotypes and the occurrence and progression of oral carcinoma in a Brazilian population. Anticancer Res 28:1023-1028.

Menoyo A, Del Rio E and Baiget M (2006) Characterization of variant alleles of cytochrome CYP2D6 in a Spanish population. Cell Biochem Funct 24:381-385. 
Millikan R, Pittman G, Tse CK, Savitz DA, Newman B and Bell D (2000) Glutathione S-transferases M1, T1, and P1 and breast cancer. Cancer Epidemiol Biomarkers Prev 9:567-573.

Mitrunen K, Jourenkova N, Kataja V, Eskelinen M, Kosma V, Benhamou S, Vainio H, Uusitupa M and Hirvonen A (2001) Glutathione S-transferase M1, M3, P1, and T1 genetic polymorphisms and susceptibility to breast cancer. Cancer Epidemiol Biomarkers Prev 10:229-236.

Olshan AF, Weissler MC, Watson MA and Bell DA (2000) GSTM1, GSTT1, GSTP1,CYP1A1, and NAT1 polymorphisms, tobacco use, and the risk of head and neck cancer. Cancer Epidemiol Biomarkers Prev 9:185-191.

Park SK, Yoo KY, Lee SJ, Kim SU, Ahn SH, Noh DY, Choe KJ, Strickland PT, Hirvonen A and Kang D (2000) Alcohol comsumption, glutathione S-transferase M1 and T1 genetic polymorphisms and breast cancer risk. Pharmacogenetics 10:301-309.

Raimondi S, Boffetta P, Anttila S, Bröckmoller J, Butkiewicz D, Cascorbi I, Clapper ML, Dragani TA, Garte S, Gsur A, et al. (2005) Metabolic gene polymorphisms and lung cancer risk in non-smokers. An update of the GSEC study. Mutat Res 59:45-57.

Rossini A, Rapozo DCM, Amorim LMF, Macedo JMB, Medina R, Neto JFN, Gallo CVM and Pinto LFR (2002) Frequencies of GSTM1, GSTT1 and GSTP1 polymorphisms in a Brazilian population. Genet Mol Res 1:233-240.

Rossini A, Soares-Lima S, Rapozo DCM, Faria M, Albano RM and Ribeiro-Pinto LF (2006) CYP2A6 and CYP2E1 polymorphisms in a Brazilian population living in Rio de Janeiro. Braz J Med Biol Res 39:195-201.

Scordo MG, Caputi AP, D'arrigo C, Fava G and Spina E (2004) Allele and genotype frequencies of CYP2C9, CYP2C19 and CYP2D6 in an Italian population. Pharmacol Res 50:195200.

Sobtia RC, Al-Badrana AI, Sharmaa S, Sharmab SK, Krishanc A and Mohand H (2005) Genetic polymorphisms of CYP2D6, GSTM1, and GSTT1 genes and bladder cancer risk in North India. Cancer Genet Cytogenet 156:68-73.

Taioli E, Gaspari L, Benhamou S, Boffetta P, Brockmoller J, Butkiewicz D, Cascorbi I, Clapper ML, Dolzan V, Haugen A, et al. (2003) Polymorphisms in CYP1A1, GSTM1, GSTT1and lung cancer below the age of 45 years. Int J Epidemiol 32:60-63.

Torresan C, Oliveira MMC, Torrezan GT, Oliveira SFV, Abuázar CS, Losi-Guembarovski R, Lima RS, Urban CA, Cavalli IJ and Ribeiro EMSF (2008) Genetic polymorphisms in oestrogen metabolic pathway and breast cancer: A positive association with combined CYP/GST genotypes. Clin Exp Med 8:65-71.

Varela-Lema L, Taioli E, Ruano-Ravina A, Barros-Dios JM, Anantharaman D, Boccia S, Bhisey RA, Cadoni G, Capoluongo E, Chen CJ, et al. (2008). Meta- and pooled analysis of GSTM1 and CYP1A1 polymorphisms and oral and pharyngeal cancers: A HuGE-GSEC review. Genet Med 10:369-384.

Wan YJ, Poland RE, Han G, Konishi T, Zheng YP, Berman N and Lin KM (2001) Analysis of the CYP2D6 gene polymorphism and enzyme activity in African-Americans in Southern California. Pharmacogenetics 11:489-499.

Wenzlaff AS, Cote ML, Bock CH, Land SJ, Santer SK, Schwartz DR and Schwartz AG (2005) CYP1A1 and CYP1B1 polymorphisms and risk of lung cancer among never smokers: A population-based study. Carcinogenesis 26:2207-2212.

Wrensch MR, Miike R, Sison JD, Kelsey KT, Liu M, McMillan A, Quesenberry C and Wiencke JK (2005) CYP1A1 variants and smoking-related lung cancer in San Francisco Bay area Latins and African Americans. Int J Cancer 113:7-141.

Wu X, Shi H, Jiang H, Kemp B, Hong WK, Delclos GL and Spitz MR (1997) Associations between cytochrome P4502E1 genotype, mutagen sensitivity, cigarette smoking and suscetibility to lung cancer. Carcinogenesis 18:967-973.

Yang CX, Matsuo K, Wang ZM and Tajima K (2005) Phase I/II enzyme gene polymorphisms and esophageal cancer risk: A meta-analysis of the literature. World J Gastroenterol 11:2531-2538.

Zembrzuski VM, Callegari-Jacques SM and Hutz MH (2006) Application of an African Ancestry Index as a genomic control approach in a Brazilian population. Ann Hum Genet 70:822-828.

Ziv E and Burchard EG (2003) Human population structure and genetic association studies. Pharmacogenomics 4:431-441.

\section{Internet Resources}

GDB - Genome Data Bank, www.gdb.org (October 5, 2005).

Associate Editor: Francisco Mauro Salzano

License information: This is an open-access article distributed under the terms of the Creative Commons Attribution License, which permits unrestricted use, distribution, and reproduction in any medium, provided the original work is properly cited. 